\title{
Pengaturan Intensitas Larutan Hara terhadap Pertumbuhan \\ Tanaman Akar Wangi (Vetiveria zizanioides L.) yang Dibudidayakan Secara Aeroponik
}

\section{Nutrients Solution Intensity Control of Vetiver (Vetiveria zizanioides L.) Growth in Aeroponic Cultivation

\author{
Endro Priherdityo, Slamet Susanto* dan Yudi Chadirin
}

\author{
Departemen Agronomi dan Hortikultura, Fakultas Pertanian, Institut Pertanian Bogor \\ (Bogor Agricultural University), J1. Meranti, Kampus IPB Darmaga, Bogor 16680, Indonesia \\ Telp. \& Faks.62-251-8629353 e-mail agronipb@indo.net.id \\ *Penulis untuk korespondensi: ssanto@cbn.net
}

Disetujui tanggal 18 Januari 2016 / Published online 25 Januari 2016

\begin{abstract}
The experiment was conducted to study the growth respons of vetiver (Vetiveria zizanioides $L$ ) in aeroponic cultivation. Aeroponic application implemented in greenhouse of University Farm IPB Dramaga, Bogor in February-May 2013. Experiment was using Randomized Complete Block Design, 4 treatments 3 replications. The treatments were 1 minute nutrients application (On) 4 minutes pause (Off) 1 seed per planting hole, 1 minutes On 4 minutes Off 2 seeds per planting hole, 2 minute On 8 minutes Off 1 seed per planting hole, 2 minutes On 8 minutes Off 2 seeds per planting hole. The result showed that the treatment of 2 minutes On 8 minutes Off 1 seed per planting hole and the treatment of 2 minutes On 8 minutes Off 2 seeds per planting hole affect on vetiver root length. The treatment of 1 minute On 4 minutes Off 2 seeds per planting hole had an highest number of roots result. All treatments did not affect to plant height, chlorophyll content, and vetiver leafes greenness. Over all, aeroponic system resulted root growth better than fields.
\end{abstract}

Key words: vetiver, aeroponics, nutrients, micro environments, vegetative

\section{ABSTRAK}

Percobaan ini dilaksanakan guna mempelajari respon pertumbuhan tanaman akar wangi atau vetiver (Vetiveria zizanioides L.) secara aeroponik. Aplikasi aeroponik dilaksanakan di greenhouse University Farm Cikabayan Kampus IPB Dramaga pada bulan Februari-Mei 2013. Percobaan menggunakan Rancangan Kelompok Lengkap Teracak, 4 perlakuan 3 ulangan. Perlakuan yang dilakukan adalah 1 menit pemberian durasi (On) 4 menit jeda (Off) 1 bibit per lubang, 1 menit On 4 menit Off 2 bibit per lubang, 2 menit On 8 menit Off 1 bibit per lubang, dan 2 menit On 8 menit Off 2 bibit per lubang. Hasil menunjukkan bahwa perlakuan 2 menit On 8 menit Off 1 bibit per lubang dan perlakuan 2 menit On 8 menit Off 2 bibit per lubang berpengaruh pada panjang akar tanaman vetiver. Perlakuan 1 menit On 4 menit Off 2 bibit per lubang memiki jumlah akar terbanyak. Seluruh perlakuan tidak berpengaruh terhadap tinggi tanaman vetiver, kandungan klorofil, dan kehijauan daun vetiver. Secara keseluruhan, sistem aeroponik menghasilkan pertumbuhan akar vetiver lebih baik dibandingkan budi daya di lahan.

Kata kunci: akar wangi, aeroponik, hara, lingkungan mikro, vegetatif 


\section{PENDAHULUAN}

Akar wangi (Vetiveria zizanoides L.) atau vetiver adalah tanaman tahunan yang termasuk famili Graminae. Tanaman ini telah lama diketahui kegunaan dan manfaatnya berupa akar dan minyak atsiri yang terkandung pada tanaman vetiver. Santoso (1993) mengungkapkan bahwa vetiver telah menjadi komoditas yang paling dicari oleh orang eropa sejak Perang Dunia I sebagai bahan baku dari parfum. Terdapat tiga produsen utama vetiver di dunia, yaitu Haiti, Bourbon Perancis di Pasifik, dan Garut di Indonesia. Setiap tahunnya, kebutuhan minyak vetiver terus meningkat. Akan tetapi, kebutuhan ini masih terkendala dari segi kuantitas dan kualitas produksi dari tanaman vetiver. Santoso (1993) serta Lutony dan Rahmayanti (1994) menyatakan bahwa produksi tanaman vetiver dari Indonesia hanya mampu memenuhi sekitar $20 \%$ dari kebutuhan minyak vetiver dunia. Rendahnya kemampuan Indonesia dalam memasok kebutuhan tanaman vetiver ini diduga karena teknik budi daya vetiver yang diterapkan oleh petani vetiver di Indonesia masih tergolong tradisional.

Damanik (1995) menemukan permasalahan dalam agroindustri vetiver di Indonesia, khususnya di Garut, adalah masalah pada tingkat produsen atau petani yang masih terkedala dengan produktivitas vetiver yang rendah dan masih menggunakan bibit jenis lokal tanpa adanya seleksi. Selain dari produktivitas, masalah vetiver lainnya dinyatakan Kardinan (2005) adalah hasil minyak vetiver yang masih belum seragam dan bermutu rendah. Salah satu solusi yang dapat dilakukan guna mengatasi masalah tersebut adalah dengan penerapan teknologi budi daya yang lebih maju. Teknologi yang lebih maju ini penting untuk diterapkan guna meningkatkan produktivitas dan kualitas dari produksi tanaman vetiver.

Salah satu teknologi maju dalam teknik budi daya adalah dengan menggunakan sistem aeroponik. Aeroponik adalah sistem bercocok tanam dalam media tanpa tanah dimana akar ditempatkan dalam media dan akar digantung serta disemprotkan larutan hara (Resh 2004). Sistem aeroponik selama ini digunakan dalam budi daya sayuran seperti selada, kubis, dan melon, serta jarang digunakan pada tanaman selain sayuran. Sistem aeroponik populer diterapkan di Israel, Itali, dan Amerika Serikat (Harris 1994).

Penerapan sistem aeroponik pada budi daya vetiver sangat memiliki peluang besar untuk meningkatkan produktivitas dan kualitas produk vetiver. Sistem aeroponik yang tanpa menggunakan tanah dapat meminimalisir kerusakan akar saat pemanenan. Roberto (2003) menjelaskan pada sistem aeroponik, tanaman memiliki kesempatan mendapatkan oksigen hingga batas maksimum yang baik dalam pertumbuhan akar, sehingga dapat mengoptimalkan pertumbuhan dan produktivitas tanaman vetiver.

Penelitian ini bertujuan untuk: (1) mendapatkan informasi pengaturan rentang waktu pengairan yang sesuai untuk tanaman vetiver, (2) mendapatkan informasi jumlah nozzle yang sesuai untuk tanaman vetiver, (3) mendapatkan informasi produktivitas dan kualitas produk tanaman vetiver yang dibudi dayakan secara aeroponik.

\section{BAHAN DAN METODE}

Penelitian dilaksanakan di greenhouse Kebun Percobaan Cikabayan Kampus IPB Dramaga (240 mdpl) pada bulan November hingga Juli 2013. Perlakuan dilaksanakan dari bulan Februari hingga Mei 2013. Pengamatan analisis kandungan klorofil dilakukan di Laboratorium Spektofotometer-UV Departemen Agronomi dan Hortikultura pada bulan Maret 2013. Pengambilan data intensitas radiasi matahari dilakukan di Stasiun Klimatologi BMKG Dramaga, Bogor pada bulan Mei 2013.

Bahan yang digunakan adalah 18 bibit tanaman vetiver varietas Verina 2 yang dikeluarkan oleh Balai Penelitian Tanaman Rempah dan Aromatik (Balitro), Larutan nutrisi AB Mix Yoshida et al. (1979), dan Styrofoam. Bibit berumur 3 bulan setelah tanam. Alat yang digunakan adalah mesin aeroponik, EC meter, $\mathrm{pH}$ meter, busa tanam, termometer ruangan dan $\mathrm{RH}$ meter, termometer akar, penggaris $30 \mathrm{~cm}$, meteran, alat Soil Plant Analysis Development (SPAD). Mesin aeroponik terdiri atas: tangki reservoir larutan hara, pompa air listrik, power button, timer, selang air, pipa PVC, nozzel, dan rangka alat.

Penelitian dilakukan dengan menggunakan Rancangan Kelompok Lengkap Teracak dengan 4 perlakuan 3 ulangan. Perlakuan yang dilakukan adalah 1 menit pemberian durasi (On) 4 menit jeda (Off) 1 bibit per lubang, 1 menit On 4 menit Off 2 bibit per lubang, 2 menit On 8 menit Off 1 bibit per lubang, dan 2 menit On 8 menit Off 2 bibit per lubang. Total keseluruhan satuan percobaan adalah 12 satuan percobaan.

Persiapan penelitian yang dilakukan berupa pemilihan bibit, penyemaian dan pembibitan, pembuatan larutan hara, penelitian pendahuluan, dan uji coba alat aeroponik. Pemilihan bibit dilakukan dengan menentukan bibit akar wangi 
yang akan digunakan dan diperbanyak. Perbanyakan bibit akar wangi Verina 2 dilakukan dengan menggunakan anakan dan ditanam pada kompos sebagai media tanam. Penyemaian dan pembibitan dilakukan di Kebun Percobaan Cikabayan yang mana satu anakan ditanam pada satu polybag berisi media tanam. Pembibitan dilakukan hingga memiliki kondisi akar yang cukup baik. Pembuatan larutan hara dilakukan dengan membuat larutan stok A dan B dengan konsentrasi berdasarkan komposisi larutan $\mathrm{AB}$ Mix Yoshida et al. (1979) dan dimodifikasi berdasarkan kebutuhan tanaman vetiver. Komponen hara yang digunakan adalah N (102.45 ppm), P (31.92 ppm), K (80.62 ppm), Ca (118.95 ppm), Mg (45.52 ppm), S (83.2 ppm), Fe (5 ppm), Mn (1.25 ppm), Zn (0.25 ppm), Mo (0.25 ppm), dan B (1 ppm). Kisaran pH larutan adalah 5-6. Uji coba alat dilakukan dengan cara mengoperasikan mesin sebelum aplikasi. Uji coba alat aeroponik ini guna mencari efisiensi penggunaan air dan kebutuhan penggunaan hara selama masa aplikasi.

Tahap penelitian selanjutnya adalah pemindahan tanam serta penerapan aplikasi aeroponik. Bahan tanam yang digunakan adalah bibit yang telah berumur 2 bulan dan dipilih dengan kriteria bibit sehat sebanyak 18 unit. Masing-masing bibit yang telah siap, kemudian ditanam di antara busa tanam sebagai penahan bibit pada rangka lubang tanam mesin. Bibit yang telah ditanam pada busa, kemudian digantung di antara rangka lubang tanam dengan akar menjulur ke bawah. Jumlah bibit per lubang tanam disesuaikan dengan desain letak perlakuan. Setelah tanaman tergantung dan sesuai dengan perlakuan, penyemprotan dilakukan sesuai dengan durasi yang telah ditentukan pada mesin.

Selama perlakuan, dilakukan pemeliharaan terhadap kondisi tanaman dan alat aeroponik. Pemeliharaan dilaksanakan selama periode tertentu, yaitu setiap hari, seminggu sekali, dan sebulan sekali. Pemeliharaan pada setiap harinya berupa pengecekan tanaman pengamatan lingkungan mikro, dan pengecekan larutan hara. Pemeliharaan periode seminggu sekali berupa pengecekan nozzle, sanitasi, pergantian larutan hara, pengamatan agronomis, dan pengendalian organisme pengganggu tanaman (OPT) jika ditemukan. Pemeliharaan pada periode bulanan adalah pengecekan mesin aeroponik dan pengamatan fisiologis berupa warna hijau daun dengan alat SPAD. Pengukuran kehijauan daun menggunakan alat SPAD dengan satuan nilai adalah unit. Pengamatan kehijauan daun dilakukan setiap bulan hingga aplikasi berakhir. Pengambilan data suhu greenhouse dilakukan setiap hari pada pagi (07.00 WIB), siang (13.00 WIB), dan sore hari (18.00 WIB). Data suhu yang diperoleh kemudian dibuat menjadi rata-rata suhu harian (Tjasyono, 2004). Pengukuran data kehilangan air dilakukan dengan menghitung nisbah volume kehilangan larutan pada tangki selama 1 hari selama aplikasi aeroponik. Pengukuran EC dilaksanakan setiap pagi dan sore hari dengan satuan ppm, kemudian dikonversikan ke satuan mmhos $\mathrm{cm}^{-1}$ mengacu kepada Whipker dan Cavins (2000).

Data agronomis dan fisiologis diolah dengan menggunakan SAS 9.0.1 guna mengetahui pengaruh perlakuan dengan menggunakan uji-F dan dilanjutkan dengan uji Duncan jika F-hitung berbeda nyata. Data lingkungan mikro diolah menggunakan Microsoft Excel guna mengetahui pola perkembangan tanaman vetiver selama penelitian berlangsung.

\section{HASIL DAN PEMBAHASAN}

\section{Pertumbuhan Vegetatif}

Peubah vegetatif digunakan untuk melihat respon pertumbuhan tanaman vetiver yang dibudi dayakan secara aeroponik. Peubah vegetatif yang diamati meliputi panjang akar $(\mathrm{cm})$, jumlah akar (unit), jumlah daun (helai), jumlah anakan (unit), dan tinggi tanaman $(\mathrm{cm})$. Hasil pengamatan selama 10 minggu setelah perlakuan (MSP) tercantum pada Tabel 1 dan Gambar 1. Hasil statistik untuk pengamatan panjang akar menunjukkan perlakuan durasi 2 menit On 8 menit Off 1 bibit per lubang dan perlakuan 2 menit On 8 menit Off 2 bibit per lubang berbeda secara nyata dibandingkan dengan perlakuan lainnya (Tabel 1). Secara umum, panjang akar tanaman vetiver secara aeroponik memiliki rentang panjang 81.33-106 cm. Pengukuran jumlah akar dilakukan secara manual dan dengan kriteria akar yang dihitung adalah akar yang sudah berdiferensiasi dan memiliki rambut akar, serta berdiameter 1-3 mm. Berdasarkan Tabel 1, perlakuan yang memiliki jumlah akar terbanyak adalah perlakuan 1 menit On 4 menit Off 2 bibit per lubang dengan jumlah akar yang dimiliki adalah 133 unit. Parameter jumlah akar (unit) tanaman vetiver berdasarkan hasil statistik menunjukkan bahwa semua perlakuan tidak berbeda nyata secara signifikan terkecuali perlakuan 2 menit On 8 menit Off 1 bibit per lubang. Pertumbuhan jumlah akar selama 10 MSP ditunjukkan pada Gambar 1B.

Jumlah daun dihitung berdasarkan kriteria daun yang sudah terbuka. Tabel 1 menunjukkan perlakuan 1 menit On 4 menit Off 2 bibit per 
lubang dan 2 menit On 8 menit Off 2 bibit per lubang berbeda nyata dibanding perlakuan lainnya dengan jumlah daun 195 dan 178 helai. Pola pertumbuhan jumlah daun tanaman vetiver selama 10 MSP menunjukkan peningkatan jumlah, terutama pada perlakuan yang memiliki jumlah bibit 2 per lubang (Gambar 1C). Jumlah anakan pada tanaman vetiver yang dibudi dayakan secara aeroponik pada Tabel 1 menunjukkan jumlah anakan tanaman vetiver pada 10 MSP memiliki rentang sekitar $12-32$ unit. Hasil statistik menunjukkan bahwa perlakuan 1 menit On 4 menit Off 1 bibit per lubang tidak berbeda nyata dengan semua perlakuan. Perlakuan 1 menit On 4 menit Off 2 bibit per lubang tidak berbeda nyata dengan 2 menit On 8 menit Off 2 bibit per lubang, tetapi berbeda nyata bila dibandingkan dengan perlakuan 2 menit On 8 menit Off 1 bibit per lubang. Pola pertumbuhan anakan tanaman vetiver (Gambar 1D) menunjukkan seluruh perlakuan memiliki pertumbuhan yang baik. Tinggi tanaman vetiver pada aplikasi aeroponik ditunjukkan pada Tabel 1. Hasil statistik menujukkan bahwa pada seluruh perlakuan tidak memiliki perbedaan yang signifikan.

Tabel 1. Tabel pengamatan parameter pertumbuhan vegetatif 10 MSP tanaman vetiver yang dibudi dayakan secara aeroponik

\begin{tabular}{|c|c|c|c|c|c|}
\hline Perlakuan & $\begin{array}{c}\text { Panjang } \\
\text { Akar }^{\mathrm{a}} \\
(\mathrm{cm})\end{array}$ & $\begin{array}{c}\text { Jumlah } \\
\text { Akar }^{\mathrm{a}} \\
\text { (unit) }\end{array}$ & $\begin{array}{l}\text { Jumlah } \\
\text { Daun }^{\text {a }} \\
\text { (helai) }\end{array}$ & $\begin{array}{l}\text { Jumlah } \\
\text { Anakan }{ }^{\text {a }} \\
\text { (unit) }\end{array}$ & $\begin{array}{l}\text { Tinggi } \\
\text { Tanaman }{ }^{\mathrm{a}} \\
(\mathrm{cm})\end{array}$ \\
\hline 1 menit On, 4 menit Off, 1 bibit per lubang & $81.33 b$ & $90.67 b$ & $125.33 b$ & $21.33 \mathrm{ab}$ & $142.33 \mathrm{a}$ \\
\hline 1 menit On, 4 menit Off, 2 bibit per lubang & $83.33 b$ & $133.00 \mathrm{a}$ & $195.00 \mathrm{a}$ & $32.00 \mathrm{a}$ & $138.33 \mathrm{a}$ \\
\hline 2 menit On, 8 menit Off, 1 bibit per lubang & $100.33 \mathrm{a}$ & $51.33 \mathrm{c}$ & $84.00 \mathrm{~b}$ & $12.33 b$ & $129.67 \mathrm{a}$ \\
\hline 2 menit On, 8 menit Off, 2 bibit per lubang & $106.00 \mathrm{a}$ & $101.33 \mathrm{ab}$ & $178.33 \mathrm{a}$ & $26.33 \mathrm{a}$ & $142.67 \mathrm{a}$ \\
\hline probabilitas & 0.00 & 0.01 & 0.00 & 0.02 & 0.34 \\
\hline $\mathrm{KK}(\%)$ & 7.35 & 20.03 & 18.40 & 26.09 & 6.68 \\
\hline
\end{tabular}

Keterangan: Angka pada kolom yang sama yang diikuti huruf yang sama menunjukkan hasil yang tidak berbeda nyata berdasarkan DMRT pada taraf $\alpha=5 \%$

Pertumbuhan panjang akar tanaman vetiver secara aeroponik lebih panjang dibandingkan dengan penanaman di lapangan (Tabel 1), yang mana rata-rata panjang akar vetiver dengan budi daya lapang adalah $30-50 \mathrm{~cm}$ pada umur panen 12-14 bulan (Santoso, 1993; Lutony dan Rahmayati, 1994). Pemberian hara secara intensif diduga mempengaruhi pertumbuhan panjang akar vetiver. Selain itu, aplikasi aeroponik juga mendukung untuk pertumbuhan panjang akar seperti pada pule pundak (Hamid, 2000), kentang (Ritter et al., 2000), tomat dan selada (Ziegler, 2005). Roberto (2003) menyatakan aeroponik mempunyai peluang meningkatkan produksi hingga 10 kali lipat dibandingkan budi daya di lahan. Pola pertumbuhan panjang akar selama 10 MSP ditunjukkan pada Gambar 1A. Secara umum, seluruh perlakuan memiliki pola pertumbuhan panjang yang baik. Pertumbuhan jumlah akar cenderung bervariasi antar masing-masing perlakuan (Tabel 1). Respon masing-masing tanaman vetiver yang berbeda-beda pada masingmasing perlakuan diduga menjadi sebab dari jumlah akar yang dihasilkan bervariasi. Ruang tumbuh akar yang lebih luas pada sistem aeroponik juga diduga mendukung pertumbuhan akar vetiver dengan baik.

Hasil pengamatan jumlah daun (Tabel 1) menunjukkan bahwa minim terjadi persaingan hara antar individu dalam satu lingkungan tumbuh selama penelitian ini berlangsung. Faktor morfologi daun vetiver yang menyirip dan mempunyai tajuk yang tegak sehingga memberikan ruang untuk tanaman tumbuh tanpa ada kompetisi yang nyata, serta sistem aeroponik yang menyediakan ruang untuk akar menyerap hara dengan bebas, diduga menjadi penyebab mengapa persaingan antar individu tanaman vetiver dalam satu lingkungan tumbuh dapat diminimalisir (Fitter dan Hay, 1991; Pagliarulo dan Hayden, 2000). Respon yang bervariatif masing-masing individu tanaman vetiver terhadap perlakuan ditunjukkan dengan jumlah anakan yang dihasilkan. Perbedaan yang tidak nyata pada pengamatan tinggi tanaman diduga disebabkan respon tanaman tidak terpengaruh oleh perlakuan yang diberikan. Gambar 1E juga menunjukkan seluruh pertumbuhan tinggi tanaman vetiver terus tumbuh selama 10 MSP dan tidak menunjukkan perbedaan yang signifkan antar perlakuan. 

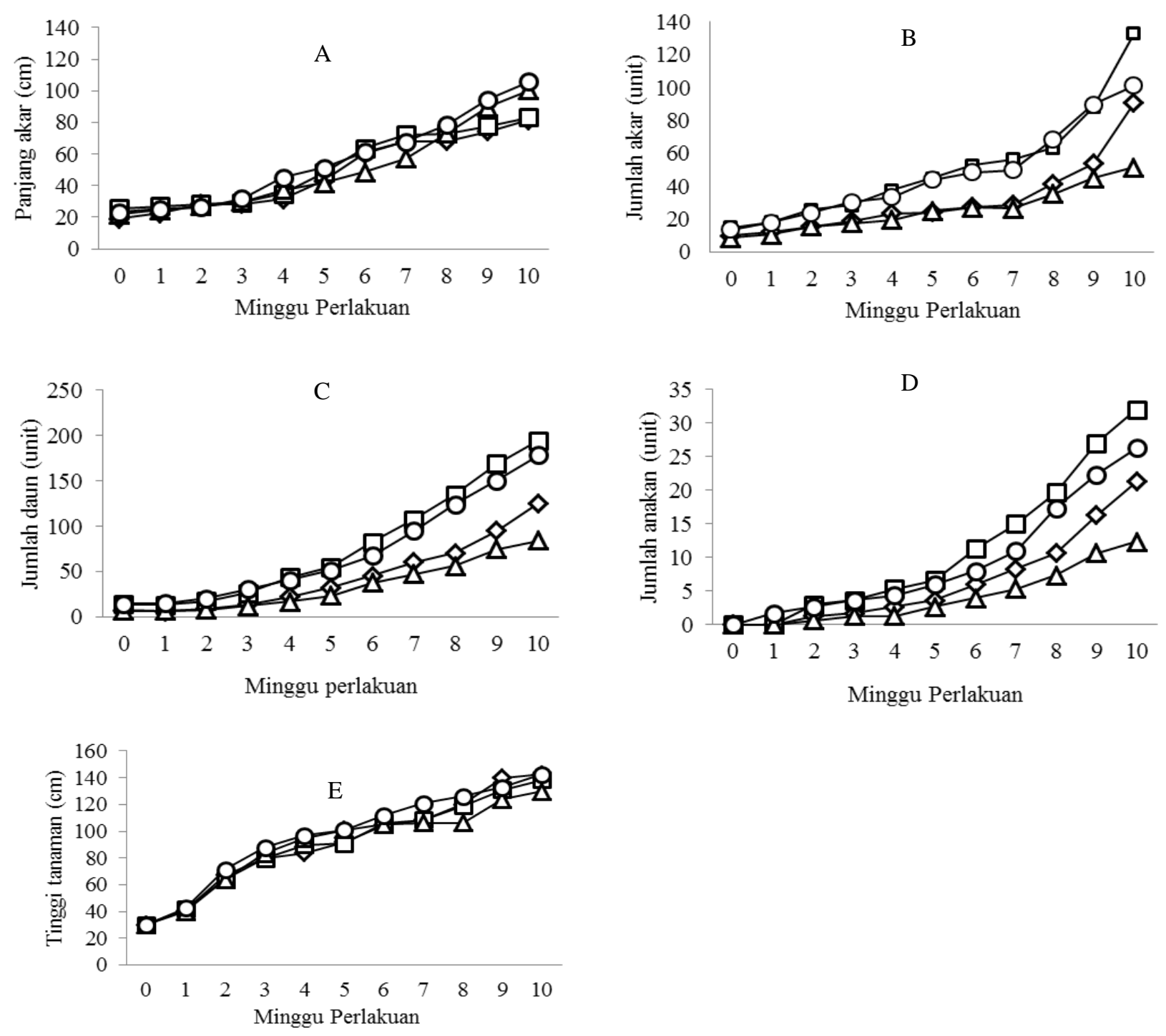

Keterangan: — $\bigcirc$ - durasi 1 menit ON 4 menit OFF dan 1 bibit per lubang — $\square$ - durasi 1 menit ON 4 menit OFF dan 2 bibit per lubang, $-\Delta$ - durasi 2 menit ON 8 menit OFF dan 1 bibit per lubang, —o- durasi 2 menit ON 8 menit OFF dan 2 bibit per lubang.

Gambar 1. Pola pertumbuhan A) panjang akar [cm]; B) jumlah akar [unit]; C) jumlah daun [unit]; D) jumlah anakan [unit]; E) tinggi tanaman [cm] vetiver secara aeroponik selama 10 MSP $(\mathrm{n}=18)$.

\section{Perkembangan Fisiologis Tanaman}

Kehijauan daun atau intensitas warna daun merupakan indikator tanaman mendapat nutrisi yang cukup. Pengamatan kehijauan daun (Tabel 2) pada bulan pertama, nilai kehijauan daun tanaman vetiver memiliki rentang 36.06-43.3 unit. Pengamatan pada bulan kedua, nilai kehijauan daun memiliki rentang 32.69-39.6 unit. Pengamatan pada bulan ketiga didapat rentang kehijauan daun vetiver aalah 54.17-70.69 unit. Secara statistik, seluruh perlakuan tidak menunjukkan perbedaan baik antar perlakuan ataupun hingga aplikasi berakhir (Tabel 2).

Hasil pengukuran kandungan klorofil pada tanaman vetiver selama aplikasi aeroponik dijelaskan pada Tabel 3. Hasil yang diperoleh menunjukkan perbandingan kandungan klorofil a, klorofil b, klorofil total, antosianin, dan karotenoid. Hasil statistik kandungan klorofil pada seluruh perlakuan menunjukkan bahwa perlakuan yang diberikan tidak berpengaruh nyata terhadap kandungan klorofil a, klorofil b, total klorofil, karotenoid, dan antosianin pada tanaman vetiver. Klorofil a yang terdapat pada tanaman vetiver memiliki rentang $2.25-2.45 \mathrm{mg} \mathrm{g}^{-1}$. Kandungan klorfil $\mathrm{b}$ pada tanaman vetiver mempunyai rentang $0.78-1.38 \mathrm{mg} \mathrm{g}^{-1}$. Karotenoid yang terdapat pada tanaman vetiver berkisar $0.48-0.53 \mathrm{mg} \mathrm{g}{ }^{-1}$. Antosianin yang terdapat pada tanaman vetiver sebesar $0.41-0.53 \mathrm{mmol} \mathrm{g}^{-1}$. 
Tabel 2. Tabel analisis kehijauan daun tanaman vetiver yang dibudi dayakan secara aeroponik

\begin{tabular}{lccc}
\hline \multicolumn{1}{c}{ Perlakuan } & Bulan 1 & Bulan 2 & Bulan 3 \\
\hline & & Unit $^{{ }^{a}}$ & \\
1 menit On, 4 menit Off, 1 bibit per lubang & $38.52 \mathrm{a}$ & $38.80 \mathrm{a}$ & $54.17 \mathrm{a}$ \\
1 menit On, 4 menit Off, 2 bibit per lubang & $42.99 \mathrm{a}$ & $38.20 \mathrm{a}$ & $62.57 \mathrm{a}$ \\
2 menit On, 8 menit Off, 1 bibit per lubang & $36.06 \mathrm{a}$ & $32.69 \mathrm{a}$ & $58.53 \mathrm{a}$ \\
2 menit On, 8 menit Off, 2 bibit per lubang & $43.30 \mathrm{a}$ & $39.60 \mathrm{a}$ & $70.69 \mathrm{a}$ \\
\hline probabilitas & 0.51 & 0.41 & 0.34 \\
KK $(\%)$ & 16.51 & 13.96 & 17.30 \\
\hline
\end{tabular}

Keterangan: Angka pada kolom yang sama yang diikuti huruf yang sama menunjukkan hasil yang tidak berbeda nyata berdasarkan DMRT pada taraf $\alpha=5 \%$

Tabel 3. Tabel analisis kandungan klorofil tanaman vetiver pada sistem aeroponik

\begin{tabular}{lccccc}
\hline \multicolumn{1}{c}{ Perlakuan } & $\begin{array}{c}\text { Klorofil a }^{\mathrm{a}} \\
\left(\mathrm{mg} \mathrm{g}^{-1}\right)\end{array}$ & $\begin{array}{c}\text { Klorofil b }^{\mathrm{a}} \\
\left(\mathrm{mg} \mathrm{g}^{-1}\right)\end{array}$ & $\begin{array}{c}\text { Klorofil }_{\text {Total }^{\mathrm{a}}} \\
\left(\mathrm{mg} \mathrm{g}^{-1}\right)\end{array}$ & $\begin{array}{c}\text {Karotenoid }^{\mathrm{a}} \\
\left(\mathrm{mg} \mathrm{g}^{-1}\right)\end{array}$ & $\begin{array}{c}\text { Antosianin }^{\mathrm{a}} \\
\left(\mathrm{mmol} \mathrm{g}^{-1}\right)\end{array}$ \\
\hline 1 menit On, 4 menit Off, 1 bibit per lubang & $2.25 \mathrm{a}$ & $0.78 \mathrm{a}$ & $3.03 \mathrm{a}$ & $0.48 \mathrm{a}$ & $0.47 \mathrm{a}$ \\
1 menit On, 4 menit Off, 2 bibit per lubang & $2.40 \mathrm{a}$ & $0.84 \mathrm{a}$ & $3.24 \mathrm{a}$ & $0.50 \mathrm{a}$ & $0.49 \mathrm{a}$ \\
2 menit On, 8 menit Off, 1 bibit per lubang & $2.38 \mathrm{a}$ & $1.38 \mathrm{a}$ & $3.76 \mathrm{a}$ & $0.53 \mathrm{a}$ & $0.41 \mathrm{a}$ \\
2 menit On, 8 menit Off, 2 bibit per lubang & $2.45 \mathrm{a}$ & $0.87 \mathrm{a}$ & $3.32 \mathrm{a}$ & $0.53 \mathrm{a}$ & $0.53 \mathrm{a}$ \\
\hline probabilitas & 0.94 & 0.43 & 0.64 & 0.81 & 0.82 \\
KK $(\%)$ & 17.14 & 20.55 & 20.80 & 11.99 & 32.00 \\
\hline
\end{tabular}

Keterangan: Angka pada kolom yang sama yang diikuti huruf yang sama menunjukkan hasil yang tidak berbeda nyata berdasarkan DMRT pada taraf $\alpha=5 \%$

\section{Kondisi Mikro Lingkungan Aeroponik}

Tjasyono (2004) menjelaskan bahwa pertumbuhan tanaman juga ikut diperngaruhi oleh iklim mikro sekitar lingkungan tumbuh tanaman. Unsur-unsur iklim yang mempengaruhi pertumbuhan tanaman ialah curah hujan, suhu, angin, sinar matahari, kelembaban, dan evapotranspirasi. Parameter iklim mikro yang diamati pada penelitian ini adalah intensitas radiasi matahari, suhu lingkungan greenhouse, suhu daerah perakaran, Electrical conductivity (EC), derajat keasaman larutan hara, kehilangan air pada sistem aeroponik.

Gambar 2A merupakan gambaran pola intensitas radiasi matahari yang diterima selama penelitian aeroponik yang diperoleh dari BMKG Stasiun Klimatologi Dramaga. Pola radiasi matahari ini tidak menunjukkan keterkaitan apabila dibandingkan dengan pola pertumbuhan vegetatif tanaman vetiver. Intensitas radiasi

fluktuasi suhu di dalam greenhouse menjadi lebih stabil dibandingkan di luar greenhouse (Kartasapoetra, 2008; Suhardiyanto, 2009). Suhardiyanto (2009) menjelaskan bahwa greenhouse di daerah tropika dibangun dengan tujuan melindungi tanaman dari hujan, serangan hama dan angin, mengurangi intensitas radiasi matahari yang berlebihan, serta mengurangi penguapan air dari daun dan media. Handoko (2009) mengungkapkan bahwa radiasi matahari dapat menyebabkan pemanasan udara di atas permukaan bumi dan menyebabkan terjadinya matahari tertinggi sekitar $1.8 \times 10^{-7} \mathrm{MJ} \mathrm{m}^{-2}$ dicapai saat $0,3,4,6$ MSP. Pertumbuhan tanaman vetiver berlangsung stabil 0-10 MSP (Gambar 1).

Kondisi suhu rata-rata harian dan kelembaban rumah kaca tempat pelaksanaan penelitian (Gambar 2C) menunjukkan bahwa suhu rata-rata selama penelitian adalah berkisar 23-34 ${ }^{\circ} \mathrm{C}$, sedangkan kelembaban greenhouse berkisar 69-90\%. Santoso (1993), Lutony dan Rahmayanti (1994) menerangkan bahwa tanaman akar wangi (vetiver) tumbuh optimum pada kisaran suhu $17-27{ }^{\circ} \mathrm{C}$. Kondisi suhu selama penelitian yang berada di kisaran suhu optimum menyebabkan tanaman vetiver masih dapat tumbuh dengan baik. Meskipun pada beberapa kondisi suhu greenhouse melebihi suhu optimum pertumbuhan vetiver, akan tetapi kondisi suhu green house masih cenderung stabil dan tidak fluktuatif seperti intensitas radiasi matahari. Kestabilan suhu dapat disebabkan sistem konstruksi dan kaca greenhouse yang menjaga penguapan. Penguapan yang meningkat menyebabkan nisbah kelembaban di udara menjadi tinggi. Struktur bangunan greenhouse yang berfungsi mengurangi intensitas radiasi matahari berlebihan inilah yang menyebabkan kelembaban udara dan suhu di dalam greenhouse menjadi cenderung stabil.

Gambar 2B menunjukkan pola suhu daerah perakaran tanaman vetiver selama aplikasi aeroponik. Secara umum, daerah perakaran berfluktuasi sekitar $22-34 \quad{ }^{\circ} \mathrm{C}$. Apabila dibandingkan dengan Gambar 2C, suhu daerah 
perakaran tidak berbeda dengan suhu greenhouse. Suhu perakaran yang baik seharusnya berada di bawah suhu lingkungan, karena apabila suhu akar terlalu tinggi dapat menyebabkan kekeringan akar akibat cepatnya kehilangan air dalam jaringan tanaman sehingga dapat menjadi cekaman bagi pertumbuhan dan perkembangan tanaman (Kartasapoetra 2008). Selama penelitian, blower
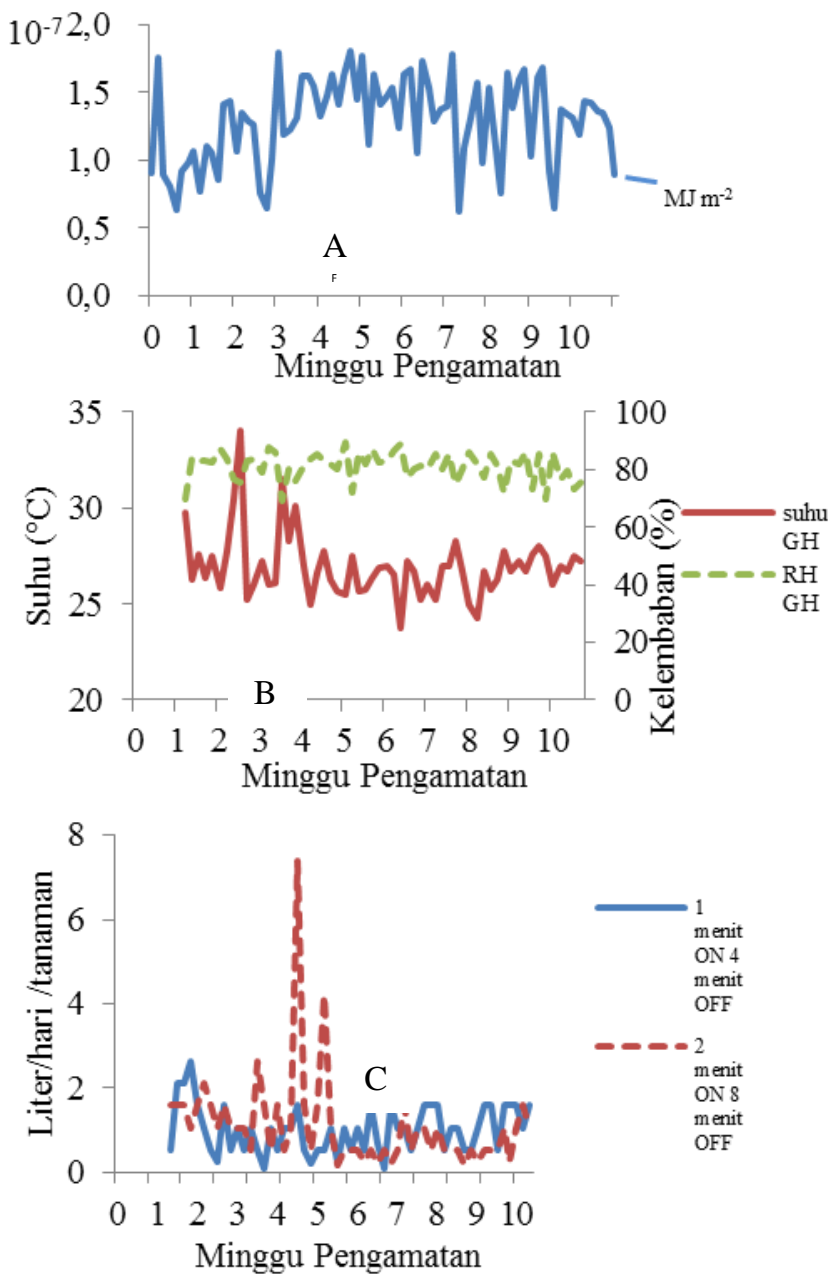

untuk penurun suhu panas daerah perakaran tidak mampu menurunkan suhu diakibatkan tingginya pengaruh suhu greenhouse terhadap suhu di dalam chamber. Meskipun suhu daerah perakaran cukup tinggi, hal tersebut tidak menghambat pertumbuhan tanaman vetiver secara signifikan seperti yang ditunjukkan pada Gambar 1
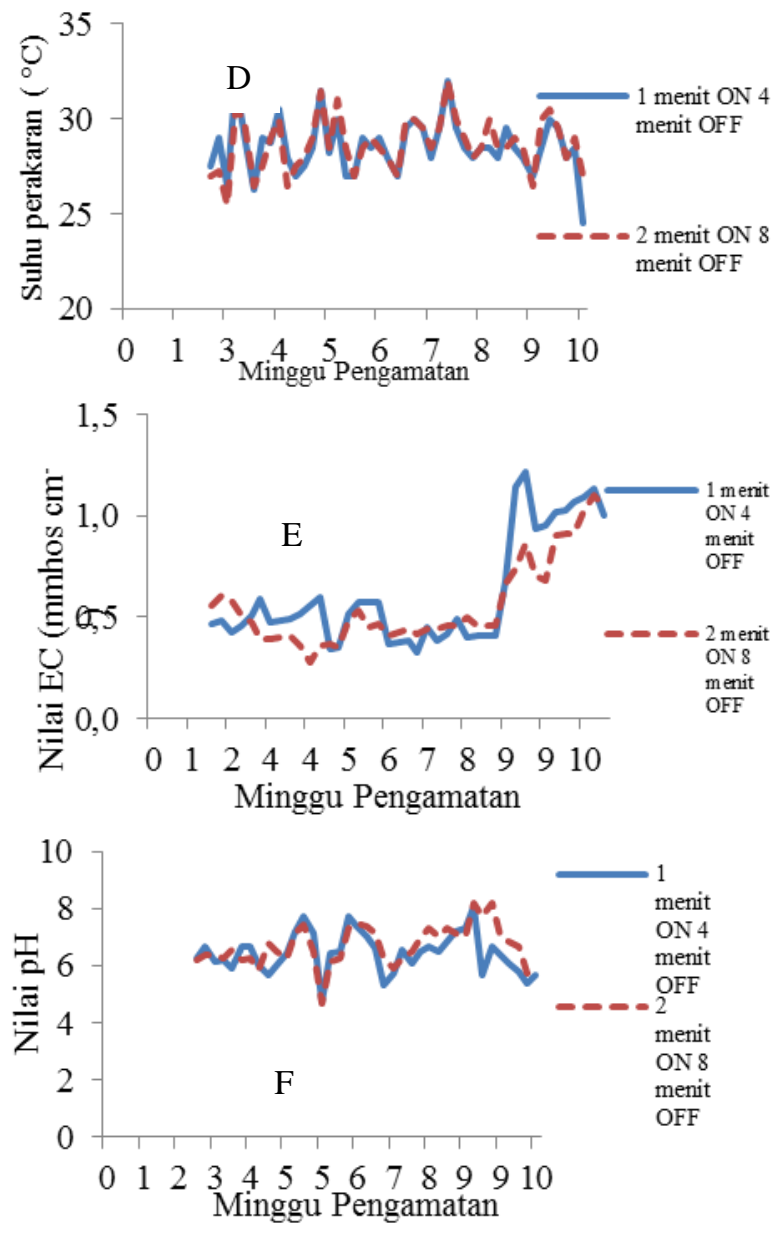

Gambar 2. Pola (A) radiasi matahari $\left[\mathrm{MJ} \mathrm{m}^{-2}\right]$, sumber: BMKG Klimatologi Dramaga; (B) suhu daerah perakaran $\left[{ }^{\circ} \mathrm{C}\right]$; (C) suhu greenhouse Cikabayan $\left[{ }^{\circ} \mathrm{C}\right]$; (D) nilai EC $\left[\right.$ mmhos $\left.\mathrm{cm}^{-1}\right]$; (E) kehilangan air [liter/hari/tanaman] pada 0-10 MSP ( $\mathrm{n}=18)$; (F) nilai derajat keasaman $[\mathrm{pH}]$. $-x$ - waktu pengisian larutan hara.

Trejo-Tollez dan Gomez-Merino (2012) menjelaskan bahwa electrical conductivity (EC) adalah metode tidak langsung pendugaan tekanan osmotik larutan hara. EC menggambarkan indeks konsentrasi garam mineral yang menggambarkan keseluruhan jumlah garam mineral pada suatu larutan. Kondisi EC selama perlakuan (Gambar 2D) menunjukkan angka yang fluktuatif. Hal tersebut dapat disebabkan dari faktor pernguapan yang terjadi pada larutan hara sehingga menyebabkan terjadinya pengendapan mineral hara di dalam larutan. Gambar 2D menujukkan lonjakan EC pada 9 MSP. Lonjakan angka EC tersebut disebabkan dari penambahan konsentrasi hara pada larutan. Secara umum, grafik EC di atas menandakan bahwa kondisi hara untuk tanaman di bawah 1.4 mmhos $\mathrm{cm}^{-1}$. Kadar EC untuk tanaman vetiver pada kondisi normal yang pernah tercatat adalah 1.414-5.020 mmhos $\mathrm{cm}^{-1}$ (CCPL, 2001). Meskipun berdasarkan pengamatan nilai EC aeroponik untuk tanaman vetiver di bawah normal, akan tetapi pertumbuhan tanaman seperti yang ditunjukkan pada Gambar 1 menandakan bahwa pertumbuhan tidak terganggu. Kondisi ini menandakan bahwa tanaman vetiver tetap dapat tumbuh dengan baik meski dalam kondisi hara 
yang sedikit atau terbatas. Selain dari keterbatasan kandungan hara, tanaman vetiver juga mampu tumbuh dalam kondisi lingkungan tumbuh yang tercemar polutan (Brandt, 2003; Chiu et al., 2003, Liao et al,. 2003).

Gambar 2E menunjukkan pola kehilangan air pada sistem aeroponik. Secara umum, kehilangan air pada aplikasi aeroponik ini berada pada kisaran 0.5-1.5 liter per hari. Kehilangan air dapat disebabkan oleh penggunaan oleh tanaman, evapotranspirasi, transpirasi oleh tanaman, ataupun kerusakan alat yang menyebabkan kehilangan air. Secara umum, kehilangan air dapat dikatakan stabil dikarenakan evapotranspirasi yang terkendali. Struktur dan konstruksi greenhouse yang menyeimbangkan radiasi dari luar yang masuk membuat pola radiasi yang menyebar di dalam greenhouse menjadi stabil.

Derajat keasaman suatu media menandakan kandungan mineral yang terdapat di dalamnya (Trejo-Tellez dan Gomez-Merino, 2012). Berdasarkan Gambar 2F, kondisi pH larutan selama perlakuan aeroponik menunjukkan fluktuasi yang beragam yang dapat disebabkan dari kondisi kandungan ion $\mathrm{H}$ yang terdapat pada larutan. Akumulasi ion $\mathrm{H}$ terpengaruh dari aktivitas kimiawi dalam larutan yang ditunjukkan dengan nilai EC (Gambar 2D). Perubahan konsentrasi ion $\mathrm{H}$ hampir mirip dengan perubahan intensitas radiasi matahari. Puncak kebasaan terjadi pada 4 MSP dan kemudian pada 5 MSP turun berubah cenderung asam. Secara umum, $\mathrm{pH}$ larutan dapat dikatakan cukup baik untuk aplikasi aeroponik karena berkisar 5-8, sedangkan $\mathrm{pH}$ yang baik untuk tanaman vetiver adalah 6-7 (Santoso, 1994). Kondisi pH yang optimum untuk tanaman dapat mencegah infeksi bakteri pada akar (Huang dan $\mathrm{Tu}, 2001$ ), membantu penyediaan nitrogen di dalam larutan atau media tanam (Zhao dan Ling, 2007), yang kemudian akhirnya dapat meningkatkan produksi tanaman (Torres et al., 2010).

\section{KESIMPULAN}

Seluruh perlakuan tidak memiliki pengaruh terhadap pertumbuhan tinggi tanaman vetiver, kandungan klorofil, dan kehijauan daun. Perlakuan 2 menit On 8 menit Off 1 bibit per lubang dan perlakuan 2 menit On 8 menit Off 2 bibit per lubang memiliki pengaruh terbaik dalam menghasilkan panjang akar tanaman vetiver yaitu 100 dan $106 \mathrm{~cm}$. Perlakuan yang memiliki jumlah akar terbanyak adalah perlakuan 1 menit On 4 menit Off 2 bibit per lubang, sebanyak 133 unit akar. Perlakuan 1 menit On 4 menit Off 2 bibit per lubang dan 2 menit On 8 menit Off 2 bibit per lubang memiliki jumlah daun serta jumlah anakan terbanyak dengan jumlah 195 dan 178 helai, serta 32 dan 26 unit anakan.

\section{DAFTAR PUSTAKA}

Brandt, R. 2003. Potential of vetiver (Vetiveria zizanioides (L.) Nash) for the use in phytoremediation of petroleum hydrocarbon-contaminated soils in Venezuela [thesis]. Münster (DE): Institut für Landschaftsökologie,Westfälische Wilhelms-Universität Münster

Chiu, K.K, Ye Z.H., Wong, M.H. 2003. Growth of Vetiveria zizanioides and Phragmities australis on $\mathrm{Pb} / \mathrm{Zn}$ and $\mathrm{Cu}$ mine tailings amended with manure compost and sewage sludge: a greenhouse study. Sciencedirect [Internet]. 2005; [diunduh 2013 Apr 10]; Bioresource Technology. 97(2006): 158170. Tersedia pada: http://www.bvsde. paho.org.

[CCPL] Codyhart Consulting Pty Ltd. 2001. Monto vetiver grass effectiveness intreating sewage effluent. [Internet]. [diunduh 2013 Juli 17]. Tersedia pada: http://www. vetiver.com.

Fitter, A.H., Hay, R.K.M. 1991. Fisiologi Lingkungan Tanaman. Andani, S., Purbayanti, E.D., penerjemah. Yogyakarta (ID): Gadjah Mada University Pr. Terjemah dari: Environmental Physiology of Plants.

Gardner, F.P., Pearce, R.B., Mitchell, R.L. 1991. Fisiologi Tanaman Budi daya. Herawati, S., penerjemah. Jakarta (ID): UI Pr. Terjemah dari: Physiology of Crop Plants.

Hamid, H. 2000. Uji coba silva aeroponik untuk budi daya pule pandak (Rauwolfia serpentine BENTH.) [skripsi]. Bogor (ID): Institut Pertanian Bogor

Handoko. 2009. Unsur-unsur cuaca dan iklim. Di dalam: Erizal, Ibnul Q, Utomo K, editor. Kumpulan Makalah Pengantar ke Ilmu-ilmu Pertanian. Bogor (ID): IPB Pr. hlm 9-15.

Harris, D. 1994. The Illustrated Guide to Hydroponics. London (GB): New Holland Publishers, Ltd.

Huang, R., Tu JC. Effect of nutrient solution $\mathrm{pH}$ on the survival and transmission of 
Clavibacter michiganensis ssp. michiganensis in hydroponically grown tomatoes. Plant Pathology [Internet]. 2001; [diunduh pada 2013 Juli 17]; 2001(50): 503508. Tersedia pada: http://onlinelibrary.wiley.com/doi/ 10.1046/j.1365-3059.2001.00586.x/pdf.

Kardinan, A. 2005. Tanaman Penghasil Minyak Atsiri. Tangerang (ID): Agromedia.

Kartasapoetra, A.G. 2008. Klimatologi: Pengaruh Iklim Terhadap Tanah dan Tanaman. Jakarta (ID): Bumi Aksara

Liao X, Luo S, Wu Y, Wang Z. 2003. Studies on the abilities of vetiveria zizanioides and cyperus alternifolius for pig farm wastewater treatment. [internet]. [diunduh 10 April 2013]. Tersedia pada: http://www.vetiver.org/ICV3Proceedings/C HN_pigwaste2.pdf.

Lutony, T.L., Rahmayati, Y. 1994. Produksi dan Perdagangan Minyak Asiri. Jakarta (ID): Penebar Swadaya.

Pagliarulo, C.L., Hayden, A.L. 2000. Potential for greenhouse aeroponic cultivation of medicinal root crops. [Internet]. 2002; [diunduh 2013 April 10]. Terdedia pada: http://aerofarms.com/wordpress/wpcontent/f iles_mf/1265411630GrowingMedicinalCro pswithAeroponics.pdf.

Resh, H.M. 2004. Hydroponic Food Production: A Definitive Guidebook of Soilless FoodGrowing Methods. $6^{\text {th }}$ Ed. New Jersey (US): Newconcept Pr, Inc.

Ritter, E., Angulo, B., Riga, P., Herran, C., Relloso, J., Jose, M.S. 2000. Comparison of hydroponic and aeroponic cultivation systems for the production of potato minitubers. Potato Research [internet]. 2000; [diunduh 2013 April 10]: 44 (2001): 127-135. Tersedia pada: http://jpkc.scau.edu.cn/soilless/papers /upload/ 2012102820544066367.pdf.

Roberto, K. 2003. How to Hydroponics. $4^{\text {th }}$ Ed. New York (US): The Futuregarden Pr.

Santoso, H.B. 1993. Akar Wangi, Bertanam dan Penyulingan. Yogyakarta (ID): Penerbit Kanisius.
Suhardiyanto, H. 2009. Teknologi hidroponik untuk budi daya tanaman. Di dalam: Erizal, Ibnul Q, Utomo K, editor. Kumpulan Makalah Pengantar ke Ilmu-ilmu Pertanian. Bogor (ID): IPB Pr. hlm 27-40.

Tjasyono, B. 2004. Klimatologi. Bandung (ID): Penerbit ITB. Ed ke-2.

Torres, A.P., Mickelbart, M.V., Lopez, R.G. 2010. Leachate volume effects on $\mathrm{pH}$ and electrical conductivity measurements in containers obtained using the pour-through method. HortTechnology [internet]. 2010; [diunduh pada 2013 Juli 17]. Juni 2010. 20(3): 608-611. Tersedia pada: http:// horttech.ashspublications.org/content/20/3/6 08.full.pdf+html?sid=75f92bd1-c353-4dafb148-f8e8c6916d25.

Trejo-Tellez, L.I., Gomez-Merino, F.C. 2012. Nutrient solution for hydroponic systems. Di dalam: toshiki a, editor. Hydroponics-a standard methodology for plant biological researches. [internet]. [diunduh pada 2013 Juli 17]. Tersedia pada: http://cdn. intechopen.com/pdfs/33765/InTechNutrient _solutions_for_hydroponic_systems.pdf.

Whipker, B.E., Cavins, T.J. 2000. Electrical conductivity (EC): units and convertions. [internet]. [diunduh pada 2013 Juli 17]. Tersedia pada: http://www.ces.ncsu.edu/ depts/hort/floriculture/Florex/EC\%20Conve rsion.pdf.

Yoshida, S., Forno, D.A., Cook, J.H., Gomez, K.A. 1979. Laboratory Manual for Physiological Studies of Rice. Los Banos (PH): IRRI.

Zhao, T., Ling, H.Q. 2007. Effects of $\mathrm{pH}$ and nitrogen forms on expression profiles of genes ivolved iniron homeostatis in tomato. Plant, Cell and Environment [internet]. 2007; [diunduh 2013 Juli 17]; 2007(30): 518-527. doi:10.1111/j.1365-3040.2007. 01638.x. Tersedia pada: http://onlinelibrary. wiley.com/doi/10.1111/j.1365.3040.2007.01 638.x/pdf.

Ziegler, R. c2005. The vertical aeroponic growing system. [internet]. c2005; [diunduh 2013 April 10]. Tersedia pada: http://www. synergyii.com/aeroponic/VAP.pdf. 